AperTO - Archivio Istituzionale Open Access dell'Università di Torino

\title{
Eosinophilic esophagitis and celiac disease
}

\section{This is the author's manuscript}

Original Citation:

Availability:

This version is available http://hdl.handle.net/2318/1682090

since 2018-11-23T17:32:00Z

Published version:

DOI:10.23736/S1121-421X.18.02504-7

Terms of use:

Open Access

Anyone can freely access the full text of works made available as "Open Access". Works made available under a Creative Commons license can be used according to the terms and conditions of said license. Use of all other works requires consent of the right holder (author or publisher) if not exempted from copyright protection by the applicable law. 


\section{Eosinophilic esophagitis and celiac disease}

Davide Giuseppe Ribaldone ${ }^{1 *}$

${ }^{1}$ Department of Medical Sciences, Division of Gastroenterology, University of Torino, Torino, Italy

Conflicts of interest: none to declare.

${ }^{*}$ Corresponding author: Davide Giuseppe Ribaldone - Department of Medical Sciences, Division of Gastroenterology, University of Torino, C.so Bramante 88 - 10126 Torino - Italy. E-mail: davrib_1998@yahoo.com Tel: +390116335208,Fax: +390116336752.

$\underline{\text { Key words: }}$ Celiac disease - Diet - Eosinophilic esophagitis - Extraintestinal 
Dear Editor,

In a recent interesting review, Alfredo Lucendo has reported on the current evidence-based diagnosis and treatment of eosinophilic esophagitis (EoE). Correctly, the author gives importance also to dietary treatment reporting several approaches described in literature. ${ }^{1}$ I would like to add some information about the potential association between EoE and celiac disease (CD). CD is a chronic, immune-mediated disorder, characterized by small intestinal malabsorption of nutrients after the ingestion of gluten by genetically susceptible individuals. For this reason, CD is considered the main relevant "gluten-related disorder", a definition that includes also wheat allergy and nonceliac gluten sensitivity. ${ }^{2}$ All occur in response to the common grain wheat or its component gluten. ${ }^{3}$

Several extraintestinal manifestations have been associated to CD. ${ }^{4}$ Both $\mathrm{CD}$ and EoE are caused by aberrant, but distinct, immune responses to ingested antigens and can be responsive to restricted food intake. In a review we reported that the prevalence of EoE in children with CD was until the $8 \%$ of the studied population. ${ }^{5}$ Hence, this finding highlights the importance of obtaining routine esophageal biopsies in children undergoing endoscopy for diagnosis of CD irrespective of whether the esophagus appears normal or abnormal at endoscopy (it could appear only slightly altered in some patients).

\section{References}

1. Lucendo AJ. Eosinophilic esophagitis: current evidence-based diagnosis and treatment in children and adults. Minerva Gastroenterol Dietol 2018;64:62-74.

2. Vasagar B, Cox J, Herion JT, Ivanoff E. World epidemiology of non-celiac gluten sensitivity. Minerva Gastroenterol Dietol 2017;63:5-15. 
3. Caio G, Riegler G, Patturelli M, Facchiano A, De Magistris L, Sapone A. Pathophysiology of non-celiac gluten sensitivity: where are we now? Minerva Gastroenterol Dietol 2017;63:16-21.

4. Ribaldone DG, Astegiano M, Fagoonee S, Rizzetto M, Pellicano R. Epilepsy and celiac disease. Panminerva Med 2011;53:213-6.

5. Pellicano R, De Angelis C, Ribaldone DG, Fagoonee S, Astegiano M. 2013 Update on celiac disease and eosinophilic esophagitis. Nutrients 2013;5:3329-36. 